\title{
INCREASE IN POTASSIUM RELEASE FROM RAT PAROTID TISSUE REPEATEDLY EXPOSED TO ISOPROTERENOL
}

\author{
Hidevo OHSHIKA, Atsushi MIYAMOTO, Haruo TAKEMURA, \\ Shinichi HATTA and Mamoru TANAKA \\ Dopartment of Pharmacology. Sapporo Medical College. Sapporo 060. Japan
}

Accepted March 16, 1983

\begin{abstract}
The effect of repeated exposure to isoproterenol (ISO) in parotid tissue was investigated with regards to potassium release in response to a successive challenge of $\alpha$ - and $\beta$-adrenergic agonists. An increase in potassium release by epinephrine was potentiated in the parotid tissue from rats repeatedly administered $1 S O$ ( $3 \mathrm{mg} / \mathrm{kg}$, three times daily for 3 days). On the other hand, a decrease in the release by ISO disappeared in 1SO-pretreated glands. Cycloheximide and actinomycin D, administered with 1 SO. completely blocked the ISO-induced development of the enhanced response to epinephrine, but not that of the reduced response to ISO. After in vitro pretreatment with ISO, the potassium release induced by a successive dose of ISO was higher than the basal release of the electrolyte. The same treatment showed a tendency to increase the response to norepinephrine. The increased release induced by a challenge dose of ISO disappeared in the tissue from cycloheximide-treated rats. The 150 -induced increase of potassium release which was caused by ISO-pretreatment in vitro was inhibited by prazosin, but not by yohimbin and propranolol. These results suggest the possibility that the $\alpha$-adrenergic response in parotid tissue might be potentiated by exposure to ISO.
\end{abstract}

Chronic administration of isoproterenol (ISO) in rats causes hyperplasia and hypertrophy of acinar cells in the salivary glands in association with the increased synthesis of DNA and proteins (1-6). Parotid glands enlarged by chronic treatment with ISO secreted larger fluid volumes than did control glands in response to pilocarpine, methoxamine or ISO. When the flow rate was expressed on the basis of gland weight, however, the enlarged glands secreted at lower rates $(3,7)$. Changes in the concentration of saliva constituents in these treated rats were also reported. The amylase concentration in parotid saliva secreted by ISO (8) or pilocarpine (3) was lower in the treated animals than in the controls, while potassium concentration in the saliva secreted by methoxamine was higher in the treated animals (7). These results may suggest that, at least, responses to both $\alpha$ - and $\beta$ adrenergic stimulation in rat parotid acinar cells would be changed by chronic administration of ISO.

In regard to potassium release from salivary acinar cells, the results of experiments using the micropuncture technique indicated that the concentrations of potassium in the original saliva at the acini-intercalated ducts were constant even if the flow rate was increased by various stimuli $(9-11)$. In in vitro experiments, $\alpha$-adrenergic agonists increased potassium release from rat submaxillar tissue, while the $\beta$-adrenergic agonist ISO decreased the basal release of potassium (12).

To analyze the nature of the altered salivary function observed in chronically ISO-treated rats, the present study was carried out using parotid slices from the treated rats and 
parotid slices exposed to ISO in vitro prior to stimulation with secretagogues, and potassium release in the presence of $\alpha$ - and $\beta$ adrenergic agonists was investigated.

\section{Materials and Methods}

Male Wistar rats weighing 220 to $240 \mathrm{~g}$ were deprived of food $20 \mathrm{hr}$ before each experiment, but were allowed water ad libitum. Under anesthesia with pentobarbital sodium (40 mg/ $\mathrm{kg}$. i.p.), the parotid glands were removed. The procedures for preparing and incubating parotid slices were carried out as described previously (13). Briefly. parotid slices were incubated at $37^{\circ} \mathrm{C}$ in Krebs-Ringer-bicarbonate buffer medium continually gassed with a $95 \% \quad \mathrm{O}_{2}-5 \% \mathrm{CO}_{2}$ mixture. After a $25 \mathrm{~min}$ preincubation, the slices were transferred into $5 \mathrm{ml}$ of frosh medium with secretagogue and were incubated for $10 \mathrm{~min}$. During this final incubation with secretagogues, $0.10 \mathrm{ml}$ samples of the medium were removed at zero time, and subsequently at 1, 2, 3, 4, 5 . 6,8 and $10 \mathrm{~min}$ for determination of the potassium concentration in the medium. At the end of the incubation, tissue slices were homogenized together with the remaining medium, and the obtained homogenates were centrifuged at $1,000 \times \mathrm{g}$ for $10 \mathrm{~min}$. The supernatants were used for determination of the potassium concentration of tissues. The potassium concentration was determined by a flame photometer using a lithium internal standard. The amount of potassium released was expressed as the percent of total potassium in the slices using the formula of Martinez et al. (12).

In vivo pretreatments with drugs were carried out as follows: (亡) ISO was injected intraperitoneally at a dose of $3 \mathrm{mg} / \mathrm{kg}$, three times daily at 8 a.m., 4 p.m. and 11 p.m. for 3 consecutive days, while the control rats were given just saline. In some experiments. actinomycin D or cycloheximide was given during the period of ISO administration. Actinomycin D was given at a dose of 125 $\mu \mathrm{g} / \mathrm{kg}$ once daily for 3 days, and cycloheximide was given at a dose of $500 \mathrm{rg} / \mathrm{kg}$ twice daily for a total of 7 doses. The parotid glands were removed $12 \mathrm{hr}$ after the last injection of these drugs.

In some of the vitro experiments, parotid slices were exposed twice to ISO. At first. the slices were incubated for $10 \mathrm{~min}$ with or without $10^{-5} \mathrm{M}$ ISO (the first dose), and then they were transferred into a fresh medium and incubated for $10 \mathrm{~min}$ without any drugs. After these treatments, the tissues were incubated again in another portion of fresh medium containing $10^{-5} \mathrm{M}$ ISO (the second dose) for $10 \mathrm{~min}$, regardless of conditions during preincubation. Adrenergic antagonists were added into the incubation medium $2 \mathrm{~min}$ before the addition of the second dose of ISO. The effect of ISO on potassium release at the final incubation was compared between the control and ISOpretreated slices. In these experiments, parotid tissues from the actinomycin $D$ - and cycloheximide-treated rats were used. These drugs were injected at a dose of $250 \mu \mathrm{g} / \mathrm{kg}$ at $24 \mathrm{hr}$ (actinomycin D) or at a dose of $500 \mu \mathrm{g} / \mathrm{kg}$ at one $\mathrm{hr}$ (cycloheximide) before sacrifice of the animals.

The Student's $t$-test was used for a statistical comparison of the mean values.

The following drugs wore used: (-) Isoproterenol $\mathrm{HCl}$ (Sigma). ( \pm ) isoproterenol $\mathrm{HCl}$ (Sooner, Kaken), (-) epinephrine bitartrate (Sigma), (-) norepinephrine $\mathrm{HCl}$ (Sigma), yohimbin $\mathrm{HCl}$ (Sigma). cycloheximide (Sigma), actinomycin D (Cosmegen ${ }^{\otimes}$, Banyu), ( \pm ) propranolol $\mathrm{HCl}$ (Indera ${ }^{\circledR}$. Sumitomo) (Sigma). Prazosin $\mathrm{HCl}$ was a gift from the Taito-Pfizer Co. (Tokyo. Japan).

\section{Results}

Effects of repeated administration of ISO 
on potassium release: Figure 1 shows the time course of potassium release from parotid tissues which were prepared from chronically ISO-treated rats. Potassium release in the parotid glands from intact rats was increased by epinephrine $\left(10^{-4} \mathrm{M}\right)$, but was decreased by ISO $\left(10^{-5} \mathrm{M}\right)$. Each value of potassium release at $5 \mathrm{~min}$ after the addition of epinephrine and ISO to the medium was $13.8 \pm 0.6$ and $0.6 \pm 0.6 \%$ of the total tissue content, respectively. The basal release of the electrolyte at the same time was $4.9 \pm 0.7 \%$.

On the contrary, in experiments using tissues from ISO-treated rats, the basal release and the response to epinephrine $\left(10^{-4}\right.$ M) were markedly enhanced. However, no response to $150\left(10^{-5} \mathrm{M}\right)$ could any longer be found.

Since the repeated administration of ISO to rats causes hyperplasia and hypertrophy of parotid acinar cells, alteration in the potassium permeability of these cell membranes may be considered possible. Potassium release was investigated by using the parotid tissue from rats which were treated with actinomycin D or cycloheximide to protect the ISO-induced hyperplasia and hypertrophy of the parotid cells. As shown in Table 1. pretreatments with actinomycin $D$ and cycloheximide had no effect on the change

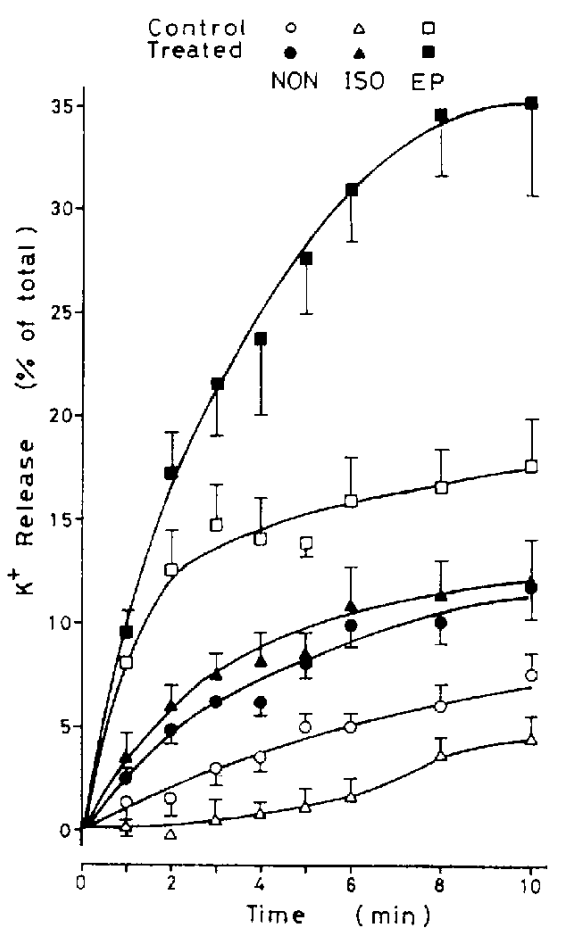

Fig. 1. Time course of potassium release from rat parotid tissue after the addition of adrenergic agonists. Each point indicates the meantS.E. ( $n$ : 5 to 7 experiments). Open symbols represent the control (intact) parotid tissue from non-treated rats and filled symbols represent the tissue from isoproterenol-treated rats. NON: no drug. $1 S O: 10^{-5} \mathrm{M}$ isoproterenol. EP: $10^{-4} \mathrm{M}$ epinephrine.

Table 1. Effects of repeated administration of isoproterenol (ISO) in rats on potassium release from isolated parotid tissue

\begin{tabular}{|c|c|c|c|c|c|c|}
\hline \multirow{2}{*}{ Pretreatment } & \multicolumn{6}{|c|}{ Potassium release (\% of total potassium in tissue) } \\
\hline & Basal & $n$ & $\begin{array}{c}\text { Isoproterenol } \\
10 \mu \mathrm{M}\end{array}$ & n & $\begin{array}{c}\text { Epinephrine } \\
100 \mu \mathrm{M}\end{array}$ & $\mathrm{n}$ \\
\hline Saline & $5.5 \pm 0.8$ & 5 & $0.7 \pm 0.9$ & 4 & $17.3 \pm 1.3$ & 4 \\
\hline isoproterenol & $8.1 \pm 0.8$ & 5 & $8.5 \pm 1.2$ & 5 & $27.6 \pm 2.9$ & 5 \\
\hline plus Actinomycin D & $8.7 \pm 0.7$ & 5 & $7.8 \pm 1.2$ & 5 & $19.7 \pm 0.5$ & 5 \\
\hline plus Cycloheximide & $7.5 \pm 0.3$ & 4 & $6.6 \pm 0.6$ & 4 & $17.1 \pm 1.9$ & 4 \\
\hline
\end{tabular}

n. Number of experiments.

Rats were treated with drugs as follows: $1 S O(3 \mathrm{mg} / \mathrm{kg}, 3$ times daily for 3 days), actinomycin D (125 $\mu \mathrm{g} /$ $\mathrm{kg}$, once daily for 3 days) and cycloheximide $(500 \mu \mathrm{g} / \mathrm{kg}$. twice daily for a total of 7 doses). The parotid glands were removed $18 \mathrm{hr}$ after the last injection of $1 \mathrm{SO}$. Each value represents the mean $\pm S . E .{ }^{*} P<0.05$ and ${ }^{* *} P<0.01$ compared with saline. Potassium release was determined at 5 min after the addition of adrenergic agonists. 
in potassium release which was observed in the tissue from 15O-treated animals, with the exception that the enhanced response to epinephrine disappeared by pretreatment with the inhibitors of protein synthesis.

Changes in potassium release resulted from in vitro exposure to ISO: To ascertain the development of alteration in potassium release from parotid tissue by repeated exposure to ISO, potassium release was examined in tissue slices exposed to 150 $\left(10^{-5} \mathrm{M}\right)$ for $10 \mathrm{~min}$ prior to challenges by

\section{$\square$ Control $\square$ ACTO $\square$ CHXM}

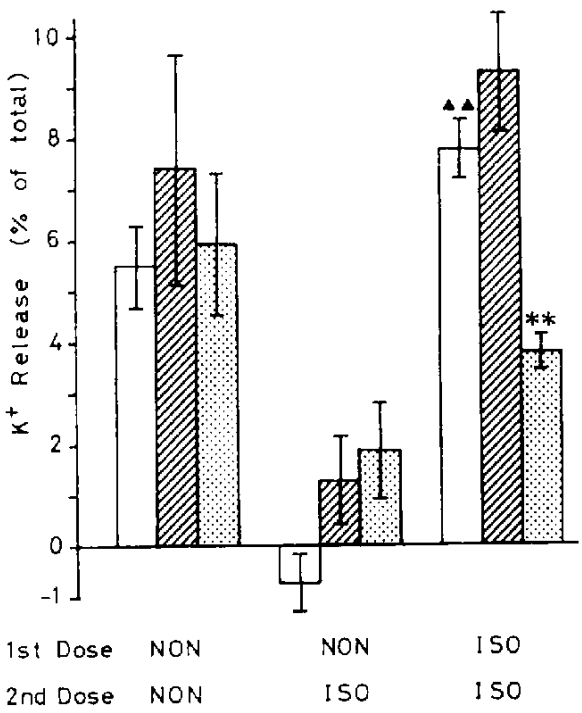

Fig. 2. Effect of pretreatment with isoproterenol (ISO) in vitro on potassium release from rat parotid tissue. Parotid tissues were prepared from rats treated with actinomycin D $(250 \mu \mathrm{g} / \mathrm{kg})$, cycloheximide $(500 \mu \mathrm{g} / \mathrm{kg})$ or no drug. After preincubation, tissues were exposed to $1 \mathrm{SO}\left(10^{-5} \mathrm{M}\right)$ for $10 \mathrm{~min}$ (the first dose), then washed with fresl: medium for $10 \mathrm{~min}$. and finally, they were incubated again with 150 $\left(10^{-5} \mathrm{M}\right)$ for measurcment of potasstum release. The vertical bar indicates the mean $\pm S$.E. $(n=5)$ at 5 min of incubation. ${ }^{*} p<0.01$ significartily difforent from the control. A $P<0.0$ i significantly different from the corresponding value in the NON NON group. The open columa, hatched column and dotted column indicate the values of each parotid tissue from control, actinomycin D (ACTD)- and cycloheximide (CHXM)-troated rats, respertively. the second dose of ISO or norepinephrine. The apparent decrease of potassium release induced by a single dose of ISO could not be observed when the tissue was twice exposed to ISO (Fig. 2), and the value in this case was higher than that of the basal release $(P<0.01)$. However, this enhancement of potassium release did not occur in the tissue from rats pretreated with cycloheximide.

As shown in Fig. 3, norepinephrineinduced potassium release appeared to be increased by an exposure to iSO prior to the addition of norepinephrine $\left(10^{-5} \mathrm{M}\right)$. The values of potassium release at $5 \mathrm{~min}$ after the start of incubation were $9.8 \pm 0.3 \%$ in intact tissues and $12.0=1.8 \%$ in 150 -exposed tissues, but the difference between these two values was not significant statistically.

To characterize the increase of potassium release observed in 150 -pretreated parotid tissue, the effects of adrenergic antagonists

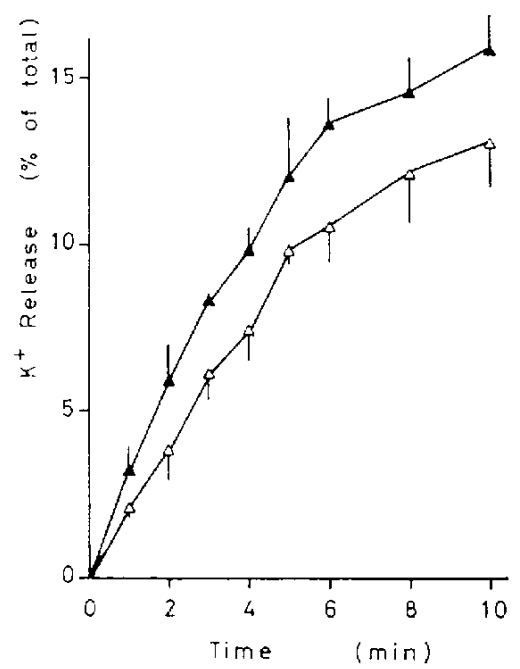

Fig. 3. Effects of norepineplune on potassium release from rat parotia tissuo. Parotid tissues were incubated for $10 \mathrm{~min}$ with or without isoproterenol $\left(10^{-5} \mathrm{M}\right)$, then washed with fresh medium for 10 min, and finally incubated with norepinephrine $(105 \mathrm{M}$ ) for measurement of potassium release. The open triangle and filled one represent the control and isoproterenol-troated groups, respectively. Vertical bars indicate the standard error. Each point was obtained from 4 experiments. 


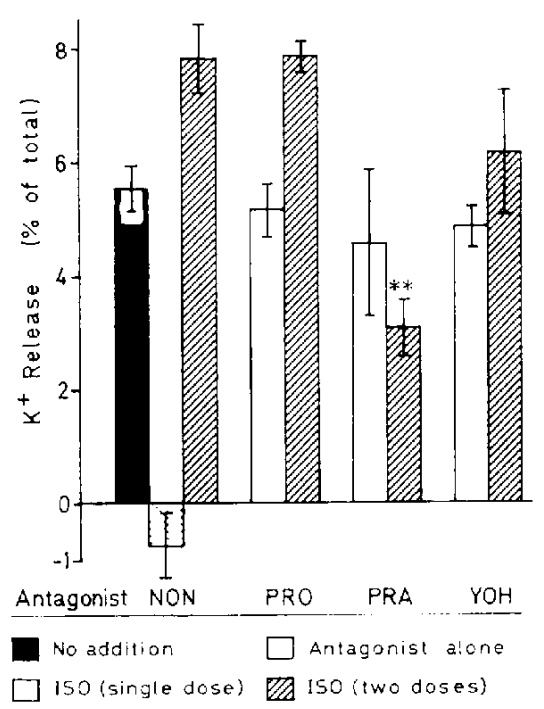

Fig. 4. Effects of adrenergic antagonists on an isoproterenol (ISO)-induced increase of potassium release in rat parotid tissue. Parotid tissues were exposed to $150\left(10^{-3} \mathrm{M}\right)$ and then incubated with fresin medium for $10 \mathrm{~min}$ prior to the incubation period for measurement of potassium release, 150 -exposed (hatched column) and control (dotted column) tissues were treated with $1 \mathrm{SO}\left(10^{-5} \mathrm{M}\right)$ for $5 \mathrm{~min}$ in the presence $o$ : absence of adrenergic antagonists. Values of potassium release in the absence of ISO are shown by a filled column (spontaneous release) and open columns (antagonist alone). Each column indicates the mean \pm S.E. ( $n$ : 5 to 7 experiments). $* P<0.01$ compared with the corresponding value of $15 O$ in the absence of antagonists. NON: no antagonist, PRO: $10^{-5} \mathrm{M}$ propranolol, PRA: $10^{-}: \mathrm{M}$ prazosin. $Y O H: 10^{-5} \mathrm{M}$ yohimbin. ISO: $10^{-5} \mathrm{M}$ isoproterenol.

on the action of the second dose of ISO were examined (Fig. 4). The increased potassium release $(7.9 \pm 0.6 \%)$ was reversed to the control level $(3.1 \pm 0.5 \%)$ by the addition of prazosin $\left(10^{-5} \mathrm{M}\right)$, and $\alpha_{1}$-antagonist, into the incubation medium. Neither yohimbin. an $\alpha_{2}$-antagonist. nor propranolol, a $\beta$ antagonist, in a concentration of $10^{-5} \mathrm{M}$ inhibited the 1SO-induced increase of potassium release (Fig. 4).

\section{Discussion}

In the present study using parotid tissue from rats which were given $1 S O$ repeatedly, the addition of ISO into the incubation medium failed to bring down the level of the basal release of potassium (Fig. 1, Table 1). These results, suggesting an ISO-induced increase of potassium influx in the intact tissue, seem to agree with results which were obtained in turkey erythrocytes (14), pigeon erythrocytes (15) and rat submaxillary glands (12). The $\beta$-antagonist could block not only the $1 \mathrm{SO}$-induced increase of potassium influx (14), but also the development of a reduced response to 150 following repeated exposure to 150 in vitro (data not shown). Coadministration of propranolol with $1 S O$ into rats resulted in no change in size of the parotid glands and no development of reduction in response to ISO challenge (16). From these results, it must be considered that the decreased response to ISO in the tissue from rats which were repeatedly administered 150 may reflect desensitization of $\beta$-adrenoceptors. After the treatment of parotid slices with ISO, its challenge dose caused an increase of potassium release which was not inhibited by the $\beta$-adrenergic antagonist (Fig. 4). Although ISO caused a similar increase of potassium release in the presence of ouabain, but this effect was inhibited by $\beta$-adrenergic antagonist ( 17 . 18). Our results may suggest that a reduction of $\beta$-adrenoceptor-mediated regulation on the action of $\mathrm{Na}^{+}, \mathrm{K}^{+}$-ATPase may be partly involved in the $1 \mathrm{SO}$-induced increase of potassium release.

The hypertrophic and hyperplastic changes in the parotid glands due to ISO may not be responsible for the decreased reactivity to isO on potassium release because a sufficient dose of cycloheximide or actinomycin D for protection of $\mathrm{ISO}$-induced enlargement of the glands could not block the development of a decreased $\beta$-adrenergic response by chronic administration of ISO (Table 1). However, in in vitro experiments, the effect of 
ISO exposure on potassium release was protected by cycloheximide (Fig. 2). Burke and Barka (19) reported that the number of specific binding sites for $\left[{ }^{3} \mathrm{H}\right]$-dihydroalprenolol in ISO-treated parotid glands was about half of the control value, while the specific activity of adenylate cyclase was not statistically different between intact and ISOtreated glands. However, it was reported that a decreased response to ISO on cyclic AMP accumulation in parotid tissue rapidly developed in vitro (16). These results may suggest that the mechanism in development of the changes might be different between short term treatment (in vitro) and relatively longer term treatment (in vivo) with ISO

The effect of $\alpha$-agonists on potassium release from parotid tissue was potentiated by in vitro and in vivo pretreatments with ISO (Table 1. Fig. 3). Recent reports suggest that increases in potassium release from parotid acinar cells by adrenergic stimulation mediate $\alpha_{1}$-adrenoceptors $(20,21)$. The ISO-induced increase of potassium release in our pretreated tissue was inhibited by an $\alpha_{1}$-type antagonist (prazosin), but not inhibited by an $\alpha_{2}$-type antagonist and a $\beta$-antagonist (Fig. 4). These results, at least, suggest that ISO-pretreatment may cause a state of increased sensitivity to $\alpha_{1}$-agonists. This possibility may be supported by the report of Abe and Dawes (7) showing that the selective $\alpha_{1}$-type agonist methoxamine induced a larger volume of parotid salivation with a higher concentration of potassium in chronically ISO-treated rats. Although there are several papers considering whether ISO may cause $\alpha$-adrenergic action (22-24). accumulation of more evidences are necessary for resolving this problem.

It is interesting that chronic administration of reserpine has caused the potentiation of the $\alpha_{1}$-type response (potassium release) and an increase in specific binding sites for $\alpha_{1}$ agonists, but no change in the $\beta$-type response (amylase release) and specific binding sites for $\beta$-agonist has been observed (20. 25). Since a surgical sympathetic denervation produced an increased response of parotid tissue to $\beta$-agonists, but did not cause enhancement of the $\alpha$-adrenergic response (26), it is plausible that both effects of reserpine and ISO on the $\alpha_{1}$-type response in salivary glands may result from prolonged impairment of neurotransmission in the sympathetic nerves. However, chronic administration of ISO has caused a decreased number of the specific binding sites for $\beta$ agonist, but no change in the sites for $\alpha$ agonists in the rat submaxillary gland (20). As shown in these findings, the mechanism of increase in specific adrenoceptors may be complicated. Although our results in experiments using cycloheximide may suggest that changes of responses to ISO are closely related to protein synthesis (Table 1, Fig. 3). further studies are required to clarify the mechanism of the development of potentiated $\alpha$-adrenergic responses by $1 S O$.

\section{References}

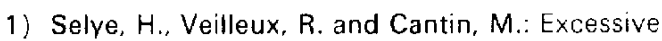
stimulation of salivary gland growth by isoproterenol. Science 133, 44-45 (1961)

2) Pahto, P.: Catecholamine-induced salivary gland enlargement in rats. Acta Odontol. Scand. 24. Supp. 45, 1-73 (1966)

3) Schneyer, C.A.: Salivary gland changes after isoproterenolinduced enlargement. Am. J. Physiol. 203, 232-236 (1962)

4) Barka, T.: Stimulation of DNA synthesis by isoproterenol in the salivary gland. Exp. Cell Res. 39, 355-364 (1965)

5) Barka, T.: Stimulation of protein and ribonucleic acid synthesis in rat submaxillary gland by isoproterenol. Lab. Invest. 18, 38-41 (1968)

6) Feiglin, B. and Reade. P.C.: Protein and DNA levels in the submandibular salivary glands of isoproterenol stimulated mice. Aust. J. Exp. Biol. Med. Sci. 56, 1-10 (1978)

7) Abe, $K$. and Dawes, $C$.: The secretion of protein and of some electrolytes in response to $\alpha$ - and $\hat{\beta}$-adrenergic agonists by at parotid and submandibular salivary glands enlarged by chronic treatment with isoproterenol. J. Dent. 
Res. 59, 1081-1089 (1980)

8) Robinovitch, M.R., Keller, P.J., Johnson, D.A., Iversen, J.M. and Kauffman, D.L.: Changes in rat parotid salivary proteins induced by chronic isoproterenol administration. J. Dent. Res. 56, 290-303 (1977)

9) Mangos, J.A., Braun, G. and Hamann, K.F.: Micropuncture study of sodium and potassium excretion in the rat parotid saliva. Pfiuegers Arch. 291, 99-106 (1966)

10) Mangos, J.A. and Braun, G.: Excretion of tota! solute. sodium and potassium in the saliva of the rat parotid gland. Pfluegers Arch, 290, 184-192 (1966)

11) Young, J.A. and Martin, C.J.: The effect of a sympatho- and a parasympathomimetic drug on the electrolyte concentrations of primary and final saliva of the rat submaxillary gland. Pfiuegers Arch. 327, 285-302 (1971)

12) Martinez, J.R., Quissell, D.O. and Giles, M. Potassium release from the rat submaxiliary gland in vitro. 1. Induction by catecholamines. J. Pharmacol. Exp. Ther. 198, 385-394 (1976)

13) Ohshika, H., Takemura, H., Endo, J. and Tanaka, M: Potentiation of isoproterenolinduced salivation by labetalol. Japan. J Pharmacol. 32, 719-720 (1982)

14) Furukawa, H., Loeb, J.N. and Bilezikian, J.P.: Beta-adrenergic receptors and isoproterenolstimulated potassium transport in erythrocytes from normal and hypothyroid turkeys. Quantitative relation between receptor occupancy and physiologic responsiveness. J. Clin. Invest. 66, 1057-1064 (1980)

15) Peričin, D., Trivić, $S$. and Leskovac, $V .:$ Influence of isoproterenol on net potassium uptake in whole pigeon erythrocytes in vitro. Biochem. Biophys. Res. Commun. 103, 647 $\rightarrow 652$ (1981)

16) Ohshika, H., Miyamoto, A. and Takemura, H.: Changes in salivary function of rat parotid tissue by repeated treatment with isoproterenol in vitro. Japan. J. Pharmacol. 32, Supp. 164P (1982)
17) Quissell, D.O.: Secretory response of dispersed rat submandibular cells. I. Potassium release. Am. J. Physiol. 238, C90-C98 (1980)

18) Butcher, F.R., Rudich, L., Emler, C. and Nemerovski, M.: Adrenergic regulation of cyclic nucleotide levels, amylase release, and potassium efflux in rat parotid gland. Mol. Pharmacol. 12, 862-870 (1976)

19) Burke, G.T. and Barka, T.: Beta-adrenergic receptors and adenylate cyclase in hypertrophic and hyperplastic rat salivary glands. Biochim. Biophys. Acta 539, 54-61 (1978)

20) Bylund, D.B., Martinez, J.R. and Pierce, D.L.: Regulation of autonomic receptors in rat submandibular gland. Mol. Pharmacol. 21, 2735 (1982)

21) Ito, H., Hoopes, M.T., Baum, B.J. and Roth, G.S.: $K^{-}$Release from rat parotid cells: An $\alpha_{1}$ adrenergic mediated event. Biochem. Pharmacol. 31, 567-573 (1982)

22) Borda, E.S., Agostini, M. del C., Gimeno, M.F. and Gimeno, A.L.: Alpha and beta sympathetic responses to isoproterenol by the isolated rat vas deferens. Pharmacol. Res. Commun. 13, 487-499 (1981)

23) Onshika, H., Endo, J., Takemura, H. and Tanaka, M.: A possible role of alpha adrenergic receptors in salivation induced by isoproterenol in mice. Japan. J. Pharmacol. 28, 650-652 (1978)

24) Curtis-Prior, P.B. and Tan, S.: Does isoprenaline have a noradrenaline-like alpha-adrenergic function, inhibitory for adipose cell lipolysis? Pharmacol. Res. Commun, 14, 199-204 (1982)

25) Martinez, J.R. and Quissell, D.O.: Potassium release from the rat submaxillary gland in vitro. III. Effects of pretreatment with reserpine. J. Pharmacol. Exp. Ther. 201, 206-217 (1977)

26) De Peusner, C.W., Stefano, F.J.E. and Perec, C.J.: Effects of sympathectomy on the in vivo $\gamma$ and $\beta$-responses of the parotid gland. Naunyn Schmiedebergs Arch. Pharmacol. 308, 211-216 (1979) 